\title{
Data report: dissolved rare earth elements (REEs) in the pore fluids of Sites U1378, U1380, U1381, and U1414 drilled during IODP Expeditions 334 and 344'
}

\author{
Jon Yang, ${ }^{2}$ Ji-Hoon Kim, ${ }^{3}$ Marta Torres, ${ }^{2}$ and Brian Haley ${ }^{2}$
}

\section{Chapter contents}

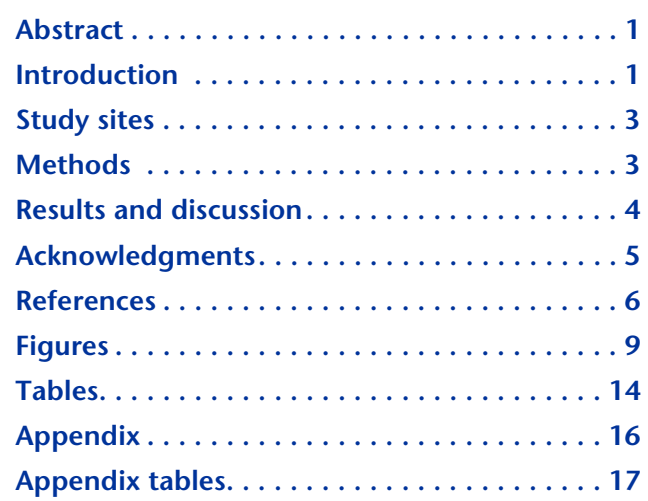

'Yang, J., Kim, J.-H., Torres, M., and Haley, B., 2018. Data report: dissolved rare earth elements (REEs) in the pore fluids of Sites U1378, U1380, U1381, and U1414 drilled during IODP Expeditions 334 and 344. In Harris, R.N., Sakaguchi, A., Petronotis, K., and the Expedition 344 Scientists, Proceedings of the Integrated Ocean Drilling Program, 344: College Station, TX (Integrated Ocean Drilling Program). doi:10.2204/iodp.proc.344.209.2018 ${ }^{2}$ College of Earth, Ocean, and Atmospheric Science, Oregon State University, 104 CEOAS Administrative Building, Corvallis OR 97331-5503, USA. Correspondence author:

jonji.yang@gmail.com

${ }^{3}$ Korea Institute of Geosciences and Mineral Resources, Daejeon 305-350, Republic of Korea.

\section{Abstract}

In this report, we present the concentrations of dissolved rare earth elements (REEs) in pore fluids recovered during International Ocean Discovery Program (IODP) Expeditions 334 and 344 from the active margin of Costa Rica. We measured dissolved REEs at three sites on the Costa Rica margin: Sites U1378/U1380 on middle slope of the continental margin and Sites U1381 and U1414 on the incoming Cocos plate. Pore fluids recovered from these cores were filtered and acidified after sampling and stored until the dissolved REEs could be measured directly using an automated chromatography preconcentration system attached to an inductively coupled plasma-mass spectrometer at Oregon State University. At Sites U1378/U1380 on the continental slope, the measured REE concentrations in the pore fluid were variable in the upper 200 meters below seafloor (mbsf), ranging from 9 to $162 \mathrm{pM}, 24$ to $120 \mathrm{pM}$, and 29 to $145 \mathrm{pM}$ for La, Dy, and Yb, respectively, representing the light, middle, and heavy REEs. Deeper than 200 mbsf at Sites U1378/U1380, measured concentrations decreased from 100 to $17 \mathrm{pM}, 10$ to $4 \mathrm{pM}$, and 50 to $10 \mathrm{pM}$ for La, $\mathrm{Dy}$, and $\mathrm{Yb}$. At Site U1381 on the incoming Cocos plate, measured concentrations peaked at $192(\mathrm{La}), 43(\mathrm{Dy})$, and $74 \mathrm{pM}(\mathrm{Yb})$ at 20 mbsf. Deeper than 80 mbsf, measured concentrations increase, particularly for the light and middle REEs, with averages of 273 (La), 38 (Dy), and $26 \mathrm{pM}(\mathrm{Yb})$. At the second site on the incoming plate, Site U1414, measured REE concentrations peak in the upper 75 mbsf and return to relatively constant values deeper than 75 mbsf. Peak concentrations of 834 (La), 223 (Dy), and 207 pM (Yb) are followed by average concentrations of $\sim 25$ (La), $\sim 10$ (Dy), and $\sim 20 \mathrm{pM}(\mathrm{Yb})$ deeper than 75 mbsf. Dissolved REE concentrations in the pore fluids were normalized to Post-Archean Australian Shale (PAAS) to evaluate relative abundances of light, middle, and heavy REEs. For all three sites, normalized concentrations show a greater abundance of heavy REEs relative to light and middle REEs. The trend for this greater relative abundance of heavy REEs is greatest for the upper portion of the sediment and becomes less pronounced downcore.

\section{Introduction}

The objective of the Costa Rica Seismogenesis Project (CRISP) undertaken by Expeditions 334 and 344 was to understand the pro- 
cesses controlling fault zone behavior during earthquake nucleation and rupture propagation at erosional subduction zones. Offshore Costa Rica, the erosional subduction zone is formed by the incoming oceanic Cocos plate subducting under the Caribbean plate. The CRISP study area is located offshore the Osa Peninsula, an area characterized by low sediment supply, fast convergence rates, abundant plate interface seismicity, and variable relief of the subducting plate along strike (see the Expedition 344 summary chapter [Harris et al., 2013a]). An important component to evaluating processes occurring at erosional subduction zones is the geochemical characterization of the interstitial pore fluids, which may yield insights to the changes in fluid-rock interactions occurring in the depths of seismogenesis. Additionally, important feedback mechanisms exist between chemical reactions in the sediments and the hydrologic characteristics of the sediments including porosity, permeability, and fluid pressure, which in turn influence the mechanical state of the plate interface at depth.

Rare earth elements (REEs) provide one tool to characterize the geochemistry of the interstitial pore fluids. REEs are categorized as the 14 naturally occurring members of the lanthanide series that share the same valence electron shell and thus display similar group chemical properties and characteristics. Importantly, however, REEs differentiate subtly in chemical reactivity as the ionic radius contracts with increasing atomic number. This slight differentiation leads to consistent and predictable fractions between the informally designated light (La to $\mathrm{Nd}$ ), middle (Sm to Dy), and heavy (Ho to Lu) REEs during physical, chemical, and biological processes (Byrne and $\mathrm{Li}$, 1995; Byrne and Sholkovitz, 1996; Elderfield and Greaves, 1982). To evaluate these relative fractionations among REEs, the standard practice is to normalize the concentrations to a reference material. For oceanic studies, the majority of REEs are sourced from continental weathering and delivery by river systems; therefore, Post-Archean Australian Shale (PAAS) is often used as the reference material (Elderfield et al., 1990; Pourmand et al., 2012; Sholkovitz et al., 1999; Taylor et al., 1981). Normalized to PAAS, dissolved oceanic REEs generally display enrichment of heavy REEs relative to middle and light REEs (e.g., De Baar et al., 1985; Elderfield and Greaves, 1982; Sholkovitz et al., 1994). This signature develops through the greater affinity of light REEs to adsorb onto marine particles and the stronger complexation of heavy REEs to dissolved carbonate, silicate, or dissolved organic compounds (e.g., Akagi, 2013; Bau and Koschinsky, 2009; Byrne and Kim, 1990; Byrne and Li, 1995). Additionally, whereas dissolved REEs exist dominantly in a +3 oxidation state, cerium (Ce) can be oxidized through microbial activity to $\mathrm{a}+4$ state that is more particle reactive, thus removing Ce from solution at a greater rate and creating a negative Ce anomaly relative to its neighboring REEs (e.g., Bau and Koschinsky, 2009; Moffett, 1990; Sholkovitz and Schneider, 1991). Europium (Eu) may also exist in a reduced +2 oxidation state, though this state is typically only observed in high-temperature reducing conditions such as those found at hydrothermal vents (e.g., Elderfield, 1988; Klinkhammer et al., 1983).

In marine pore fluids, the signatures of dissolved REEs have been documented and associated with various diagenetic reactions in the sediments, although understanding the diagenetic cycling of REEs is still incomplete (e.g., Abbott et al., 2015; Haley et al., 2004; Kim et al., 2012; Sholkovitz et al., 1989). In the oxic zone of the sediments, pore fluid REE measurements attributable to particulate organic carbon (POC) show linear enrichment of heavy REEs relative to light REEs, reflecting remineralization from POC and complexation of heavy REEs to dissolved organic carbon (DOC) (Haley et al., 2004). Conversely, measurements of fresh, labile organic matter in the sediments that had been isolated through an $\mathrm{H}_{2} \mathrm{O}_{2}$ extraction have shown middle-REE enrichment (Freslon et al., 2014). In the ferruginous zone of the sediments, where the respiration of organic matter continues through the reductive dissolution of $\mathrm{Fe}$ oxides, a characteristic middle-REE enriched signal in the pore fluids has been observed by several studies (Abbott et al., 2015; Du et al., 2016; Haley et al., 2004). Although there has been some debate as to the mechanisms behind the middle-REE enrichment, Fe oxide phases isolated through hydroxylamine and dithionite extractions have shown similar middleREE enrichments, suggesting that the pore fluid signatures in this zone are a direct consequence of $\mathrm{Fe}$ oxide dissolution (Abbott et al., 2016; Du et al., 2016). In the methanogenic zone of the sediment column, dissolved REEs in the pore fluids take on a heavy-REE enriched pattern (Kim et al., 2012; SoyolErdene and Huh, 2013). A recent study of methanotrophs in the Deepwater Horizon oil spill has demonstrated that light REEs ( $\mathrm{La}, \mathrm{Ce}, \mathrm{Pr}$, and $\mathrm{Nd}$ ) are important cofactors in methanol dehydrogenase, providing a mechanism for a pore fluid signal depleted in light REEs relative to heavy REEs in methanogenic sediments (Shiller et al., 2017).

For the CRISP sites, we measured the pore fluid signals at three different locations and from four different cores: Sites U1378/U1380 from the middle slope 
on the continental margin, Site U1381 from the incoming plate, and Site U1414, also from the incoming plate (Fig. F1). We used a relatively novel sample preconcentration system (seaFAST2 from Elemental Scientific, Inc., Omaha, NE) with direct introduction to an inductively coupled plasma-mass spectrometer (ICP-MS) to measure REEs in these pore fluids.

\section{Study sites}

Site U1378 was drilled during Expedition 334 in the middle slope of the Costa Rica margin, $\sim 38 \mathrm{~km}$ offshore the Osa Peninsula and $24 \mathrm{~km}$ from Caño Island (Fig. F1). This location is situated above an unlocked portion of the plate boundary, as defined by interpolate earthquake relocation and geodetic measurements, and the upper plate sediment representing the older framework wedge is overlaid by $\sim 750 \mathrm{~m}$ of slope sediments (LaFemina et al., 2009; Expedition 334 Scientists, 2012a; Vannucchi et al., 2016). This older framework wedge, however, was not reached during drilling at Site U1378 or at complementary Hole U1380A because of unfavorable drilling conditions (Expedition 334 Scientists, 2012b). The sediment composition at Site U1378 is marked by a monotonous sequence of silty clay to clay alternating with widely interspersed centimeter-scale sandy layers. Hole U1380C was drilled during Expedition 344 as a complementary site to Site U1378. The goal for drilling Site U1380 was to reach the deeper portions of the upper slope sequence and underlying framework wedge sequences (see the Expedition 344 summary chapter [Harris et al., 2013a]). The sediment recovered from this site was characterized by an alternating, terrestrially sourced, turbiditic upper slope to shelf sequence (see the Mid-slope Site U1380 chapter [Harris et al., 2013d]). Given the complementary locations of Site U1378 and Hole U1380C, we combine the pore fluid data from the two sites to refer to general characterization of the Costa Rica upper slope.

On the incoming plate, Site U1381 was drilled in line with Sites U1378/U1380 to characterize the sediment and oceanic crust entering the seismogenic zone (Fig. F1). The upper $50 \mathrm{~m}$ of Site U1381 is composed of a monotonous silty clay to clay sequence and is underlain by a sequence characterized by abundant biogenic components and reflecting pelagic sediments (see the Input Site U1381 chapter [Harris et al., 2013b]). Site U1414 is also situated on the incoming plate but is $\sim 1 \mathrm{~km}$ seaward of the deformation front offshore the Osa Peninsula and northwest of Site U1381 (see the Input Site U1414 chapter [Harris et al., 2013c]).

\section{Methods}

\section{Pore fluid sampling}

Whole-round cores recovered, cut, and capped on the catwalk were taken to the shipboard laboratory. Samples collected between the seafloor and 50 meters below seafloor (mbsf) were processed in a nitrogen-filled glove bag to avoid oxidation of redox-sensitive elements. All other samples were processed under ambient atmospheric conditions. Cores were generally processed within $24 \mathrm{~h}$ of recovery and were kept capped in a nitrogen-filled environment at $4^{\circ} \mathrm{C}$ until processing. For pore fluid collection, after extrusion from the core liner the surface of each wholeround sample was carefully scraped with a spatula to remove potential contamination from seawater and sediment smearing. The sediment was then loaded into a titanium squeezer, modeled after the stainless steel squeezer of Manheim and Sayles (1974), and subjected to pressures as high as $30 \mathrm{MPa}$ but generally $<20 \mathrm{MPa}$ using a hydraulic press. As the sediment is pressurized and squeezed, pore fluid passes through a prewashed Whatman Number 1 filter and titanium screen into an acid-washed $60 \mathrm{~mL}$ plastic syringe attached to the bottom of the squeezer assembly. The pore fluid is then passed through an additional $0.2 \mu \mathrm{m}$ Gelman polysulfone disposable filter and subsampled into acid-washed high-density polyethylene bottles. For trace-metal and REE analysis, the pore fluid samples were preserved with the addition of ultraclean $\mathrm{HNO}_{3}$ to $\mathrm{pH}<2$ and stored at $4^{\circ} \mathrm{C}$ until analysis onshore.

\section{REE concentration measurement}

We measured pore fluid REE concentrations using the seaFAST2 system from Elemental Scientific, Inc., attached as the sample introduction unit to a Thermo X-Series II ICP-MS. The seaFAST2 system uses an ion exchange column with ethylenediaminetriacetic acid/iminodiacetic acid functional groups to selectively preconcentrate transition metals and REEs. An ammonium acetate buffer prepared as 14.5 $\mathrm{M}$ ammonium hydroxide and $17.4 \mathrm{M}$ glacial acetic acid washes out the alkali and alkaline earth-matrix elements from the column. A solution of $2 \mathrm{M} \mathrm{HNO}_{3}$ then elutes the REEs from the column and onto the ICP-MS for quantification. Of the alkali and alkaline earth elements, $\mathrm{Ba}^{2+}$ is particularly problematic for the analysis of REEs because $\mathrm{Ba}^{2+}$ can form oxides in the plasma that interfere with the signal of both ${ }^{153} \mathrm{Eu}$ and ${ }^{151} \mathrm{Eu}$, Eu's two main isotopes. For the pore fluid samples in this study in particular, dissolved $\mathrm{Ba}^{2+}$ averaged $\sim 1.5 \mu \mathrm{M}$, although values could reach as high as $18 \mu \mathrm{M}$ in some cases (see the Expedition 
344 summary chapter [Harris et al., 2013a]). Before the REEs can be accurately measured, the signal from Ba must be removed or corrected for in the measured Eu signals. The seaFAST2 system is well-suited to separating the $\mathrm{Ba}^{2+}$ signals from REEs in seawater, thereby minimizing the potential of isobaric interferences from the formation of oxides (e.g., Hathorne et al., 2012; Yang and Haley, 2016). The timing of the $\mathrm{Ba}^{2+}$ peak during the elution step was closely monitored to ascertain that there was no significant contribution from $\mathrm{BaO}$ formation on the $\mathrm{Eu}$ peak. The ICP-MS instrument was tuned to minimize oxide formation in the plasma by monitoring the formation of $\mathrm{CeO}$, which was measured and minimized to levels of $<2 \%$ formation.

Analytical precision was monitored through replicate measurements $(N=19)$ of an in-house seawater standard (NBP1097) and was quantified with a relative standard deviation of $<8 \%$ for all REEs except for Sm at $11 \%$, Ce at $20 \%$, and Gd at $22 \%$ (Table T1). External reproducibility was monitored through replicate analyses $(N=10)$ of the PPREE1 acid mine drainage reference material diluted 10,000-fold to match the REE concentrations with that of seawater and pore fluid and found to fall within one standard deviation of the most probable values reported by Verplanck et al. (2001) (Table T1). Detection limits were determined as three times the standard deviation of the blank signals and are listed in Table T1. Average method blank levels were below these detection limits. Sample aliquots and instrument operating conditions for each analytical run are given in the "Appendix."

\section{Results and discussion}

We present the measurements of dissolved pore fluid REEs in Tables T2, T3, and T4. To illustrate the downhole behavior of dissolved REEs as a series, we selected representative members of the light, middle, and heavy REE groups: La, Dy, and $\mathrm{Yb}$, respectively. Downhole profiles of alkalinity, $\mathrm{NH}_{4}^{+}$, and $\mathrm{Ba}^{2+}$ in the pore fluids are shown to contextualize the dissolved REE profiles with the major geochemical characteristics of the sediment column (see the Expedition 344 summary chapter [Harris et al., 2013a]). Dissolved concentrations of REEs are normalized to PAAS, and representative ratios of $(\mathrm{Dy} / \mathrm{La})_{\mathrm{N}},(\mathrm{Yb} / \mathrm{La})_{\mathrm{N}}$, and $(\mathrm{Yb} / \mathrm{Dy})_{\mathrm{N}}$, where ${ }_{\mathrm{N}}$ represents the normalized values, are shown to assess the degree the relative abundances of the light, middle, and heavy REEs to one another. Ratios of other representative members of the light, middle, and heavy REEs did not vary ap- preciably from the chosen ratios or affect interpretation. Ratios of a composite average of light, middle, and heavy REEs also did not diverge significantly from the interpreted results.

\section{Sites U1378/U1380}

REEs measured in pore fluids of the upper slope of Costa Rica show great variability in the upper 200 mbsf, with La ranging from 9 to $162 \mathrm{pM}$, Dy from 24 to $120 \mathrm{pM}$, and $\mathrm{Yb}$ from 29 to $145 \mathrm{pM}$ (Fig. F2A; Table T2). REEs in this upper 200 mbsf interval also display relatively greater abundances of middle and heavy REEs over light REEs (Fig. F2B). The highest normalized ratios occur at $24 \mathrm{mbsf}$, where $(\mathrm{Dy} / \mathrm{La})_{\mathrm{N}}$ is $41,(\mathrm{Yb} / \mathrm{La})_{\mathrm{N}}$ is 190 , and $(\mathrm{Yb} / \mathrm{Dy})_{\mathrm{N}}$ is 5 . This sample depth also corresponds to the lowest concentrations of La and Dy in the upper 200 mbsf of the sediments. Yb concentration at this depth is $97 \mathrm{pM}$, which is significantly higher than $\mathrm{La}$ and $\mathrm{Tb}$, accounting for the elevated ratios. What accounts for the low concentrations of light and middle REEs in this sample, especially relative to the surrounding samples, is less clear, but we cannot discredit the validity of this signal that is above our detection limits and within the reported error. Comparatively, ratios in the upper $200 \mathrm{mbsf}$, not including the $24 \mathrm{mbsf}$ sample, average $\sim 8$ for $(\mathrm{Dy} / \mathrm{La})_{\mathrm{N}}, \sim 18$ for $(\mathrm{Yb} / \mathrm{La})_{\mathrm{N}}$, and $\sim 2$ for $(\mathrm{Yb} / \mathrm{Dy})_{\mathrm{N}}$. Overall, normalized patterns of dissolved REEs in the upper 200 mbsf interval are characterized as increasing from light to heavy REEs (Fig. F2C).

Deeper than 200 mbsf, REE concentrations distinctly decrease with depth in the core. In this interval, La decreases from $\sim 100$ to $\sim 10 \mathrm{pM}$, Dy from $\sim 10$ to $\sim 4$ $\mathrm{pM}$, and $\mathrm{Yb}$ from $\sim 50$ to $\sim 2 \mathrm{pM}$ (Fig. F2A). The relative abundances of middle and heavy REEs over light REEs are elevated but less so than in the upper 200 mbsf interval (Fig. F2B). Normalized ratios average $\sim 5$ for $(\mathrm{Dy} / \mathrm{La})_{N_{N}} \sim 9$ for $(\mathrm{Yb} / \mathrm{La})_{N_{N}}$, and $\sim 2$ for $(\mathrm{Yb} / \mathrm{Dy})_{\mathrm{N}}$. Compared to the REE patterns of the upper 200 mbsf, the lower depths in the sediment at the slope site are relatively flat (Fig. F2C).

Although there is no discernible correlation between REEs and $\mathrm{NH}_{4}{ }^{+}$or $\mathrm{Ba}^{2+}$ throughout the entire core, a relatively strong relationship exists between REEs and alkalinity, particularly in the lower depths of the core (Fig. F3). For pore fluid samples deeper than 200 mbsf, the $R^{2}$ values for a linear regression between REEs and alkalinity are 0.8886, 0.9807, and 0.9554 for $\mathrm{La}, \mathrm{Dy}$, and $\mathrm{Yb}$, respectively. If we extrapolate these linear relationships to the interval shallower than $200 \mathrm{mbsf}$, the data show a net deficit relative to 
the alkalinity for $\mathrm{La}$ and $\mathrm{Tb}$ in a number of samples. By contrast, extrapolating the linear relationship for $\mathrm{Yb}$ shows a slight net surplus in the upper 200 mbsf.

\section{Site U1381}

On the incoming plate at Site U1381, the discernible characteristic of dissolved REEs in pore fluids is localized maxima in concentrations at $\sim 20 \mathrm{mbsf}$ for $\mathrm{La}$, $\mathrm{Dy}$, and $\mathrm{Yb}$ and increases, particularly in La concentrations, deeper than 80 mbsf (Fig. F4A; Table T3). In the uppermost pore fluid sample from the upper 2 mbsf of the sediment, concentrations of light and middle REEs are elevated, with $\mathrm{La}=192 \mathrm{pM}$, Dy $=43$ $\mathrm{pM}$, and $\mathrm{Yb}=36 \mathrm{pM}$. Comparatively, in samples from 8 and 14 mbsf dissolved concentrations of La, $\mathrm{Dy}$, and $\mathrm{Yb}$ average $\sim 60, \sim 28$, and $\sim 46 \mathrm{pM}$, respectively. These dissolved REE concentrations reach local maxima of 193, 76, and 74 for $\mathrm{La}, \mathrm{Tb}$, and $\mathrm{Yb}$, respectively, at $\sim 20 \mathrm{mbsf}$ before decreasing to averages of $\sim 60, \sim 17$, and $\sim 20 \mathrm{pM}$ between 40 and 80 mbsf. Deeper than $80 \mathrm{mbsf}$, concentrations of light and middle REEs are particularly elevated, averaging 273 , 38 , and $26 \mathrm{pM}$ for $\mathrm{La}, \mathrm{Tb}$, and $\mathrm{Yb}$, respectively, for the three samples measured in this interval.

Normalized REE ratios generally show greater abundances of middle and heavy REEs relative to light REEs throughout the core (Fig. F4B). These ratios are relatively constant throughout the upper $80 \mathrm{mbsf}$, averaging $\sim 3, \sim 8$, and $\sim 2$ for $(\mathrm{Dy} / \mathrm{La})_{\mathrm{N}},(\mathrm{Yb} / \mathrm{La})_{\mathrm{N}}$, and $(\mathrm{Yb} / \mathrm{Dy})_{\mathrm{N}}$, respectively. An exception is the sample at 50 mbsf, which shows elevated ratios of 10,41 , and 4 for $(\mathrm{Dy} / \mathrm{La})_{\mathrm{N}},(\mathrm{Yb} / \mathrm{La})_{\mathrm{N}}$, and $(\mathrm{Yb} / \mathrm{Dy})_{\mathrm{N}}$, respectively. These elevated values may be an artifact of the relatively low concentrations of REEs because this particular sample records the lowest values for the entire core. For the three samples deeper than $80 \mathrm{mbsf}$, normalized ratios are the lowest in the core, averaging 2, 2, and 1 for $(\mathrm{Dy} / \mathrm{La})_{\mathrm{N}},(\mathrm{Yb} / \mathrm{La})_{\mathrm{N}}$, and $(\mathrm{Yb} / \mathrm{Dy})_{\mathrm{N}}$. These ratios are reflected in the overall normalized REE patterns, with the deepest samples plotting below samples from the upper depths of the sediment (Fig. F4C). By comparison, REEs measured in the framework wedge of Site U1381 exhibit concentrations that are orders of magnitude greater than in the pore fluids and show moderate anomalies in the Eu signal and a relatively greater abundance of heavy REEs over light REEs (see Yan and Shi, 2016) (Fig. F5). Unlike dissolved REEs in the pore fluids of slope Sites U1378/U1380, no observable correlation exists between REEs and alkalinity at the incoming plate Site U1381.

\section{Site U1414}

At the second site on the incoming plate, Site U1414, dissolved REEs in the pore fluids are characterized by a general peak in concentrations in the upper 75 mbsf of the sediment and relatively low, constant values deeper than 75 mbsf (Fig. F6A, Table T4). In this upper 75 mbsf, REEs reach maximum values of 834, 223, and $207 \mathrm{pM}$ for $\mathrm{La}$, Dy, and $\mathrm{Yb}$, respectively. Deeper than 75 mbsf, REE profiles are fairly constant, averaging $\sim 25, \sim 10$, and $\sim 20 \mathrm{pM}$ for La, Dy, and $\mathrm{Yb}$. The exception to this profile are two samples at 200 and $\sim 250$ mbsf, where $\mathrm{La}$ is 197 and $108 \mathrm{pM}$, respectively, Dy is 37 and $20 \mathrm{pM}$, and $\mathrm{Yb}$ is 38 and 20 pM. Normalized REE ratios indicate a greater abundance of heavy REEs, particularly centered around 100 mbsf (Fig. F6B). In general, the deepest pore fluid samples in this core have the lowest normalized ratios and the flattest overall patterns, which is consistent with REEs at Sites U1381 and U1378/U1380 (Fig. F6C). REEs measured in the framework wedge underlying these sediments are consistent with the framework wedge at Site U1381, showing orders of magnitude greater concentrations than the pore fluids, with moderate anomalies in the Eu signal and relatively greater abundances of the heavy compared to the light REEs (see Yan and Shi, 2016) (Fig. F5).

REEs at Site U1414 show a general positive correlation with pore fluid alkalinity, although linear regressions are relatively weak, with $R^{2}$ values of 0.418 , 0.529 , and 0.672 for alkalinity correlations with La, Dy, and $\mathrm{Yb}$, respectively (Fig. F7). Pore fluid REEs also show a slight positive correlation with dissolved $\mathrm{Ba}^{2+}$, except in the $\mathrm{Ba}^{2+}$ peak deeper than $300 \mathrm{mbsf}$ (Fig. F8). For the interval not including the $\mathrm{Ba}^{2+}$ peak, the $R^{2}$ values for a linear regression between $\mathrm{Ba}^{2+}$ and REEs are $0.4874,0.6068$, and 0.5611 for $\mathrm{La}$, $\mathrm{Dy}$, and $\mathrm{Yb}$, respectively. The concentrations of $\mathrm{Ba}^{2+}$ in this interval, however, is relatively low, with values between 0.5 and $\sim 2 \mu \mathrm{M}$.

\section{Acknowledgments}

This data report was greatly improved with the comments and suggestions of an anonymous reviewer. This research used samples and data provided by the International Ocean Discovery Program (IODP), which is sponsored by the US National Science Foundation and international partners. This research was financially supported by awards from Korea Integrated Ocean Drilling Program (K-IODP) of Ministry 
of Oceans and Fisheries (MOF) to J.-H. Kim and by US Science Support Program (USSSP) postcruise research awards T334B11 and T344A11 (Expeditions 334 and 344) to M. Torres.

\section{References}

Abbott, A.N., Haley, B.A., and McManus, J., 2016. The impact of sedimentary coatings on the diagenetic $\mathrm{Nd}$ flux. Earth and Planetary Science Letters, 449:217-227. https://doi.org/10.1016/j.epsl.2016.06.001

Abbott, A.N., Haley, B.A., McManus, J., and Reimers, C.E., 2015. The sedimentary flux of dissolved rare earth elements to the ocean. Geochimica et Cosmochimica Acta, 154:186-200.

https://doi.org/10.1016/j.gca.2015.01.010

Akagi, T., 2013. Rare earth element (REE)-silicic acid complexes in seawater to explain the incorporation of REEs in opal and the "leftover" REEs in surface water: new interpretation of dissolved REE distribution profiles. Geochimica et Cosmochimica Acta, 113:174-192. https://doi.org/10.1016/j.gca.2013.03.014

Bau, M., and Koschinsky, A., 2009. Oxidative scavenging of cerium on hydrous Fe oxide: evidence from the distribution of rare earth elements and yttrium between Fe oxides and $\mathrm{Mn}$ oxides in hydrogenetic ferromanganese crusts. Geochemical Journal, 43(1):37-47. https://doi.org/10.2343/geochemj.1.0005

Byrne, R.H., and Kim, K.-H., 1990. Rare earth element scavenging in seawater. Geochimica et Cosmochimica Acta, 54(10):2645-2656. https://doi.org/10.1016/0016-7037(90)90002-3

Byrne, R.H., and Li, B., 1995. Comparative complexation behavior of the rare earths. Geochimica et Cosmochimica Acta, 59(22):4575-4589. https://doi.org/10.1016/0016-7037(95)00303-7

Byrne, R.H., and Sholkovitz, E.R., 1996. Marine chemistry and geochemistry of the lanthanides. In Gschneidner, K.A., Jr., and Eyring, L. (Eds.), Handbook on the Physics and Chemistry of Rare Earths, 23:497-593. https://doi.org/10.1016/S0168-1273(96)23009-0

De Baar, H.J.W., Bacon, M.P., Brewer, P.G., and Bruland, K.W., 1985. Rare earth elements in the Pacific and Atlantic Oceans. Geochimica et Cosmochimica Acta, 49(9):1943-1959. https://doi.org/10.1016/0016-7037(85)90089-4

Du, J., Haley, B.A., and Mix, A.C., 2016. Neodymium isotopes in authigenic phases, bottom waters and detrital sediments in the Gulf of Alaska and their implications for paleocirculation reconstruction. Geochimica et Cosmochimica Acta, 193:14-35.

https://doi.org/10.1016/j.gca.2016.08.005

Elderfield, H., 1988. The oceanic chemistry of the rareearth elements. Philosophical Transactions of the Royal Society, A: Mathematical, Physical \& Engineering Sciences, 325:105-126. https://doi.org/10.1098/rsta.1988.0046

Elderfield, H., Upstill-Goddard, R., and Sholkovitz, E.R., 1990. The rare earth elements in rivers, estuaries, and coastal seas and their significance to the composition of ocean waters. Geochimica et Cosmochimica Acta,

54(4):971-991.

https://doi.org/10.1016/0016-7037(90)90432-K

Elderfield, H., and Greaves, M.J., 1982. The rare earth elements in seawater. Nature, 296(5854):214-219.

http://dx.doi.org/10.1038/296214a0

Expedition 334 Scientists, 2012a. Expedition 334 summary. In Vannucchi, P., Ujiie, K., Stroncik, N., Malinverno, A., and the Expedition 334 Scientists, Proceedings of the Integrated Ocean Drilling Program, 334: Tokyo (Integrated Ocean Drilling Program Management International, Inc.).

https://doi.org/10.2204/iodp.proc.334.101.2012

Expedition 334 Scientists, 2012b. Site U1378. In Freslon, N., Bayon, G., Toucanne, S., Bermell, S., Bollinger, C., Chéron, S., Etoubleau, J., Germain, Y., Khripounoff, A., Ponzevera, E., and Rouget, M.-L., 2014. Rare earth elements and neodynium isotopes in sedimentary organic matter. Geochimica et Cosmochimica Acta, 140:177-198. https://doi.org/10.1016/j.gca.2014.05.016

Haley, B.A., Klinkhammer, G.P., and McManus, J., 2004. Rare earth elements in pore waters of marine sediments. Geochimica et Cosmochimica Acta, 68(6):1265-1279. https://doi.org/10.1016/j.gca.2003.09.012

Harris, R.N., Sakaguchi, A., Petronotis, K., Baxter, A.T., Berg, R., Burkett, A., Charpentier, D., Choi, J., Diz Ferreiro, P., Hamahashi, M., Hashimoto, Y., Heydolph, K., Jovane, L., Kastner, M., Kurz, W., Kutterolf, S.O., Li, Y., Malinverno, A., Martin, K.M., Millan, C., Nascimento, D.B., Saito, S., Sandoval Gutierrez, M.I., Screaton, E.J., Smith-Duque, C.E., Solomon, E.A., Straub, S.M., Tanikawa, W., Torres, M.E., Uchimura, H., Vannucchi, P., Yamamoto, Y., Yan, Q., and Zhao, X., 2013a. Expedition 344 summary. In Harris, R.N., Sakaguchi, A., Petronotis, K., and the Expedition 344 Scientists, Proceedings of the Integrated Ocean Drilling Program, 344: College Station, TX (Integrated Ocean Drilling Program).

https://doi.org/10.2204/iodp.proc.344.101.2013

Harris, R.N., Sakaguchi, A., Petronotis, K., Baxter, A.T., Berg, R., Burkett, A., Charpentier, D., Choi, J., Diz Ferreiro, P., Hamahashi, M., Hashimoto, Y., Heydolph, K., Jovane, L., Kastner, M., Kurz, W., Kutterolf, S.O., Li, Y., Malinverno, A., Martin, K.M., Millan, C., Nascimento, D.B., Saito, S., Sandoval Gutierrez, M.I., Screaton, E.J., Smith-Duque, C.E., Solomon, E.A., Straub, S.M., Tanikawa, W., Torres, M.E., Uchimura, H., Vannucchi, P., Yamamoto, Y., Yan, Q., and Zhao, X., 2013b. Input Site U1381. In Harris, R.N., Sakaguchi, A., Petronotis, K., and the Expedition 344 Scientists, Proceedings of the Integrated Ocean Drilling Program, 344: College Station, TX (Integrated Ocean Drilling Program).

https://doi.org/10.2204/iodp.proc.344.103.2013

Harris, R.N., Sakaguchi, A., Petronotis, K., Baxter, A.T., Berg, R., Burkett, A., Charpentier, D., Choi, J., Diz Ferreiro, P., Hamahashi, M., Hashimoto, Y., Heydolph, K., Jovane, L., Kastner, M., Kurz, W., Kutterolf, S.O., Li, Y., Malinverno, A., Martin, K.M., Millan, C., Nascimento, D.B., Saito, S., Sandoval Gutierrez, M.I., Screaton, E.J., 
Smith-Duque, C.E., Solomon, E.A., Straub, S.M., Tanikawa, W., Torres, M.E., Uchimura, H., Vannucchi, P., Yamamoto, Y., Yan, Q., and Zhao, X., 2013c. Input Site U1414. In Harris, R.N., Sakaguchi, A., Petronotis, K., and the Expedition 344 Scientists, Proceedings of the Integrated Ocean Drilling Program, 334: Tokyo (Integrated Ocean Drilling Program Management International, Inc.).

https://doi.org/10.2204/iodp.proc.344.104.2013

Harris, R.N., Sakaguchi, A., Petronotis, K., Baxter, A.T., Berg, R., Burkett, A., Charpentier, D., Choi, J., Diz Ferreiro, P., Hamahashi, M., Hashimoto, Y., Heydolph, K., Jovane, L., Kastner, M., Kurz, W., Kutterolf, S.O., Li, Y., Malinverno, A., Martin, K.M., Millan, C., Nascimento, D.B., Saito, S., Sandoval Gutierrez, M.I., Screaton, E.J., Smith-Duque, C.E., Solomon, E.A., Straub, S.M., Tanikawa, W., Torres, M.E., Uchimura, H., Vannucchi, P., Yamamoto, Y., Yan, Q., and Zhao, X., 2013d. Mid-slope Site U1380. In Harris, R.N., Sakaguchi, A., Petronotis, K., and the Expedition 344 Scientists, Proceedings of the Integrated Ocean Drilling Program, 344: College Station, TX (Integrated Ocean Drilling Program). https://doi.org/10.2204/iodp.proc.344.106.2013

Hathorne, E.C., Haley, B., Stichel, T., Grasse, P., Zieringer, M., and Frank, M., 2012. Online preconcentration ICPMS analysis of rare earth elements in seawater. Geochemistry, Geophysics, Geosystems, 13(1):Q01020. https://doi.org/10.1029/2011GC003907

Kim, J.-H., Torres, M.E., Haley, B.A., Kastner, M., Pohlman, J.W., Riedel, M., and Lee, Y.-J., 2012. The effect of diagenesis and fluid migration on rare earth element distribution in pore fluids of the northern Cascadia accretionary margin. Chemical Geology, 291:152-165. https://doi.org/10.1016/j.chemgeo.2011.10.010

Klinkhammer, G., Elderfield, H., and Hudson, A., 1983. Rare earth elements in seawater near hydrothermal vents. Nature, 305(5931):185-188. https://doi.org/10.1038/305185a0

LaFemina, P., Dixon, T.H., Govers, R., Norabuena, E., Turner, H., Saballos, A., Mattioli, G., Protti, M., and Strauch, W., 2009. Fore-arc motion and Cocos Ridge collision in Central America. Geochemistry, Geophysics, Geosystems, 10(5):Q05S14. https://doi.org/10.1029/2008GC002181

Manheim, F.T., and Sayles, F.L., 1974. Composition and origin of interstitial waters of marine sediments, based on deep sea drill cores. In Goldberg, E.D. (Ed.), The Sea (Volume 5): Marine Chemistry: The Sedimentary Cycle: New York (Wiley), 527-568.

Moffett, J.W., 1990. Microbially mediated cerium oxidation in seawater. Nature, 345(6274):421-423. https://doi.org/10.1038/345421a0

Pourmand, A., Dauphas, N., and Ireland, T.J., 2012. A novel extraction chromatography and MC-ICP-MS technique for rapid analysis of REE, Sc and Y: revising Cl-chondrite and Post-Archean Australian Sahle (PAAS) abundances. Chemical Geology, 291:38-54.

https://doi.org/10.1016/j.chemgeo.2011.08.011

Ross, N., Torres, M.E., Haley, B.A., Solomon, E.A., and Kastner, M., 2015. Data report: strontium isotope analyses of pore fluids from the CRISP-A transect drilled during Expeditions 334 and 344. In Harris, R.N., Sakaguchi, A., Petronotis, K., and the Expedition 344 Scientists, Proceedings of the Integrated Ocean Drilling Program, 344: Tokyo (Integrated Ocean Drilling Program Management International, Inc.). https://doi.org/10.2204/iodp.proc.344.201.2015

Shiller, A.M., Chan, E.W., Joung, D.J., Redmond, M.C., and Kessler, J.D., 2017. Light rare earth element depletion during Deepwater Horizon blowout methanotrophy. Scientific Reports, 7:10389.

https://doi.org/10.1038/s41598-017-11060-z

Sholkovitz, E.R., Elderfield, H., Szymczak, R., and Casey, K., 1999. Island weathering: river sources of rare earth elements to the western Pacific Ocean. Marine Chemistry, 68(1-2):39-57. https://doi.org/10.1016/S0304-4203(99)00064-X

Sholkovitz, E.R., Landing, W.M., and Lewis, B.L., 1994. Ocean particle chemistry: the fractionation of rare earth elements between suspended particles and seawater. Geochimica et Cosmochimica Acta, 58(6):1567-1579. https://doi.org/10.1016/0016-7037(94)90559-2

Sholkovitz, E.R., Piepgras, D.J., and Jacobsen, S.B., 1989. The pore water chemistry of rare earth elements in Buzzards Bay sediments. Geochimica et Cosmochimica Acta, 53(11):2847-2856. https://doi.org/10.1016/0016-7037(89)90162-2

Sholkovitz, E.R., and Schneider, D.L., 1991. Cerium redox cycles and rare earth elements in the Sargasso Sea. Geochimica et Cosmochimica Acta, 55(10):2737-2743. https://doi.org/10.1016/0016-7037(91)90440-G

Soyol-Erdene, T.-O., and Huh, Y., 2013. Rare earth element cycling in the pore waters of the Bering Sea slope (IODP Exp. 323). Chemical Geology, 358:75-89. https://doi.org/10.1016/j.chemgeo.2013.08.047

Taylor, S.R., McLennan, S.M., Armstrong, R.L., and Tarney, J., 1981. The composition and evolution of the continental crust: rare earth element evidence from sedimentary rocks. Philosophical Transactions of the Royal Society A: Mathematical, Physical and Engineering Sciences, 301(1461):381-399. https://doi.org/10.1098/rsta.1981.0119

Vannucchi, P., Morgan, J.P., Silver, E.A., and Kluesner, J.W., 2016. Origin and dynamics of depositionary subduction margins. Geochemistry, Geophysics, Geosystems, 17(6):1966-1974. https://doi.org/10.1002/2016GC006259

Verplanck, P.L., Antweiler, R.C., Nordstrom, D.K., and Taylor, H.E., 2001. Standard reference water samples for rare earth element determinations. Applied Geochemistry, 16(2):231-244.

https://doi.org/10.1016/S0883-2927(00)00030-5 
Yan, Q., and Shi, X., 2016. Data report: major and trace element and $\mathrm{Sr}-\mathrm{Nd}-\mathrm{Pb}$ isotope analyses for basement rocks from the CRISP-A transect drilled during Expeditions 334 and 344. In Harris, R.N., Sakaguchi, A., Petronotis, K., and the Expedition 344 Scientists, Proceedings of the Integrated Ocean Drilling Program, 344: College Station, TX (Integrated Ocean Drilling Program).

https://doi.org/10.2204/iodp.proc.344.205.2016
Initial receipt: 7 March 2018

Acceptance: 11 July 2018

Publication: 2 November 2018

MS 344-209 
Figure F1. Drilling location map, adapted from Ross et al. (2015). A. Study area location off the Pacific coast of Costa Rica. CRISP = Costa Rica Seismogenesis Project. B. Site locations drilled during Expeditions 334 and 344. Yellow circles $=$ sites analyzed for pore fluid REEs in this report. C. Schematic depicting the subduction of the Cocos plate under the Caribbean plate and the locations of Sites U1378/U1380 and Site U1381 along transect $\mathrm{A}-\mathrm{A}^{\prime}$.

A

B

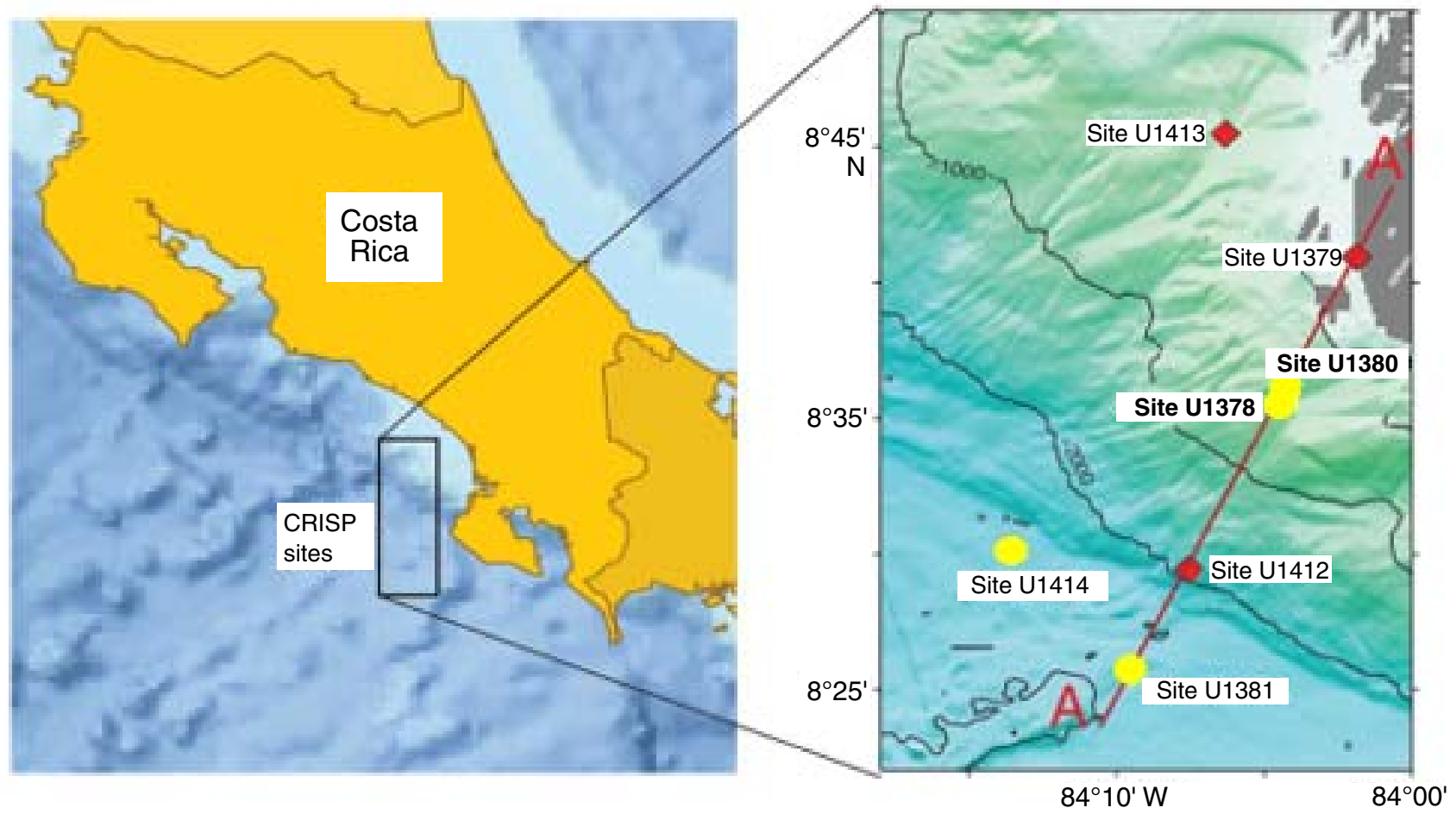

C

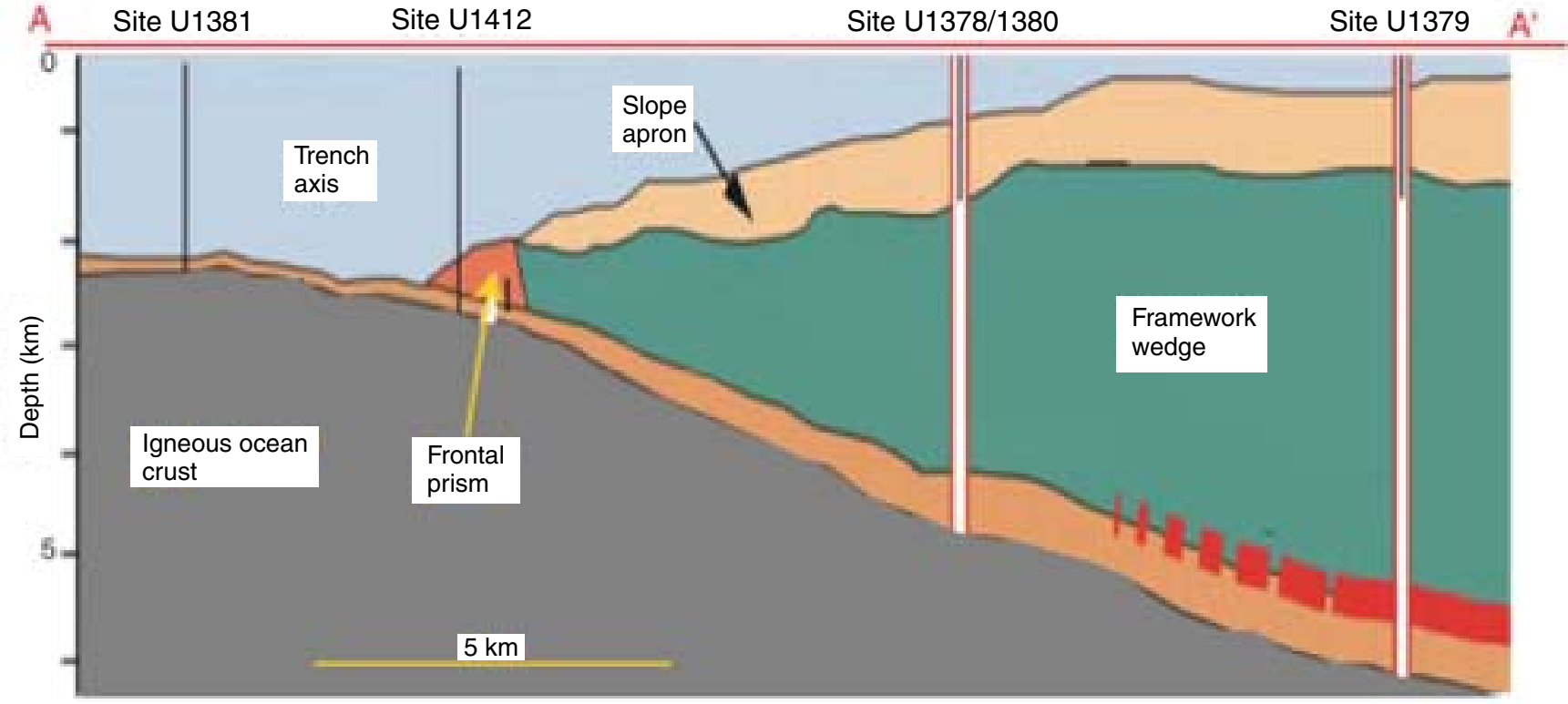


Figure F2. Pore fluid REE concentrations, Sites U1378/U1380. Darker to lighter colored symbols represent samples from close to the surface of the sediment to increasing depth. A. Alkalinity, $\mathrm{NH}_{4}^{+}$, and $\mathrm{Ba}^{2+}$ (from Harris et al., 2013d) and La, Dy, and $\mathrm{Yb}$ concentrations representing the light, middle, and heavy REEs, respectively. B. PAAS-normalized $(\mathrm{Tb} / \mathrm{La})_{\mathrm{N}},(\mathrm{Yb} / \mathrm{La})_{\mathrm{N}}$, and $(\mathrm{Yb} / \mathrm{Tb})_{\mathrm{N}}$ ratios showing relative abundances of the light, middle, and heavy REEs to each other. C. PAAS-normalized REE patterns.

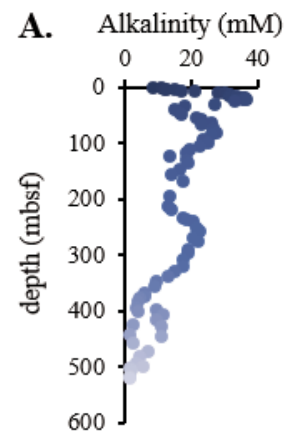

B.

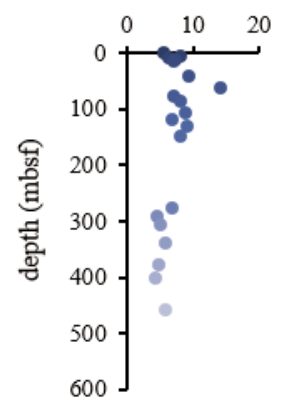

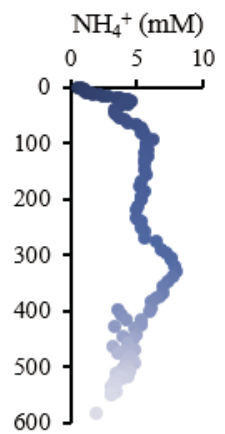

$(\mathrm{Yb} / \mathrm{La})_{\mathrm{N}}$

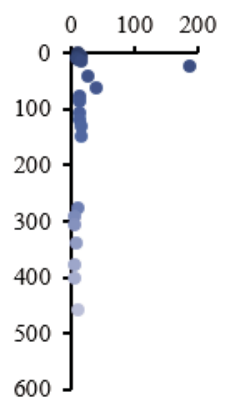

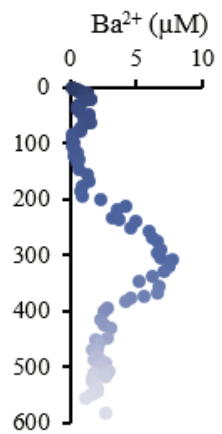

$(\mathrm{Yb} / \mathrm{Dy})_{\mathrm{N}}$

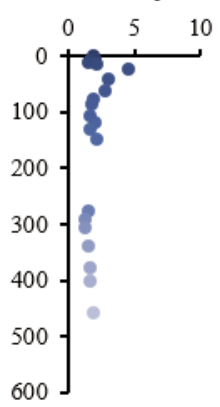

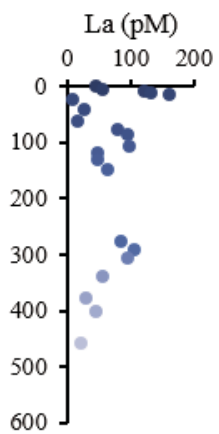
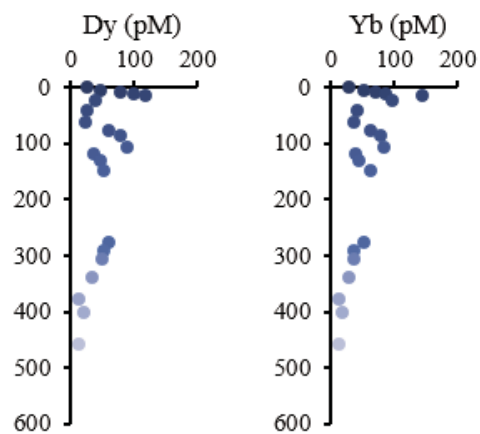

C.

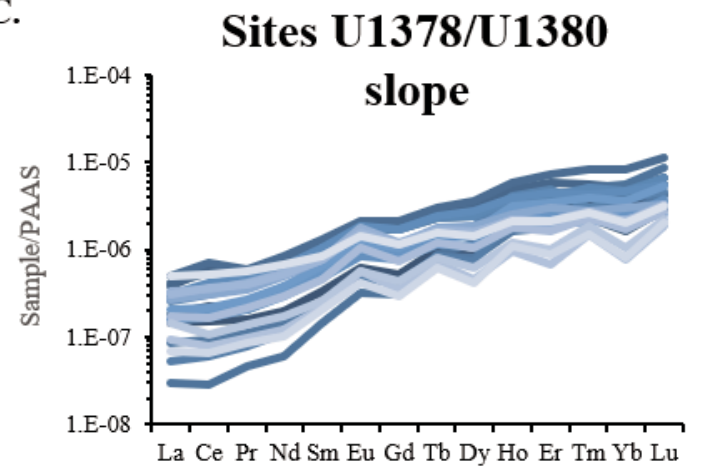

Figure F3. Correlations between pore fluid REE concentrations and alkalinity, Sites U1378/U1380. Color and shading patterns correlate with depth profile shown in Figure F2. Square symbols = samples from deeper than 200 mbsf, dotted line = linear regression for samples deeper than $200 \mathrm{mbsf}$.
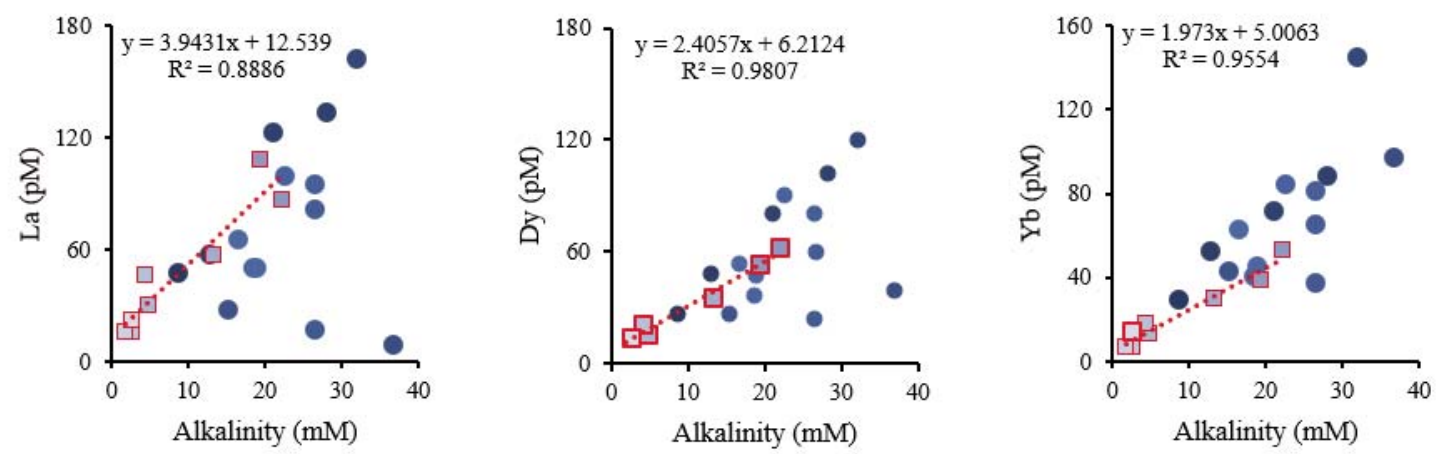
Figure F4. Pore fluid REE concentrations, Site U1381. Darker to lighter colored symbols represent samples from close to the surface of the sediment to increasing depth. A. Alkalinity, $\mathrm{NH}_{4}{ }^{+}$, and $\mathrm{Ba}^{2+}$ (from Harris et al., 2013d) and $\mathrm{La}$, Dy, and $\mathrm{Yb}$ concentrations representing the light, middle, and heavy REEs, respectively. B. PAAS-normalized $(\mathrm{Tb} / \mathrm{La})_{\mathrm{N}},(\mathrm{Yb} / \mathrm{La})_{\mathrm{N}}$, and $(\mathrm{Yb} / \mathrm{Tb})_{\mathrm{N}}$ ratios showing relative abundances of the light, middle, and heavy REEs to each other. C. PAAS-normalized REE patterns.

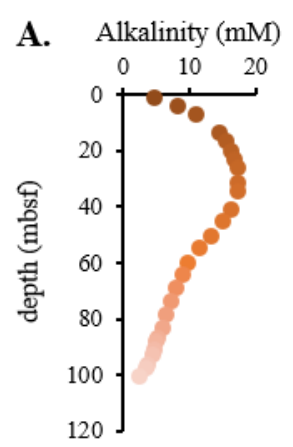

B.

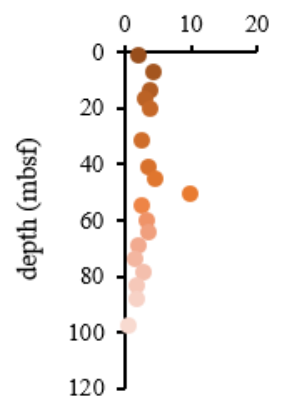

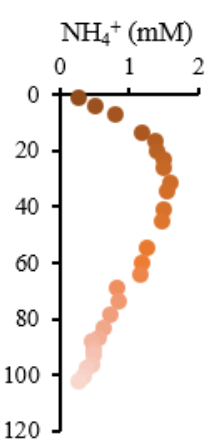

$(\mathrm{Yb} / \mathrm{La})_{\mathrm{N}}$

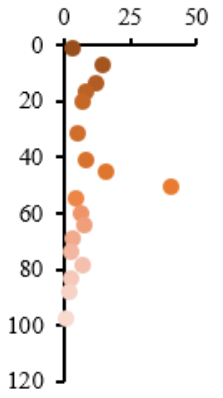

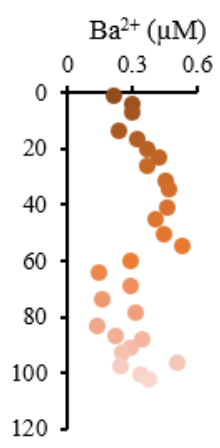

$(\mathrm{Yb} / \mathrm{Dy})_{\mathrm{N}}$

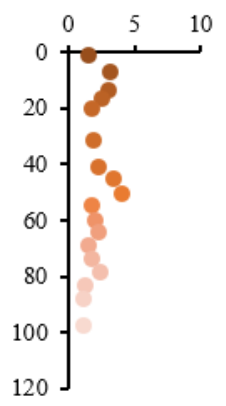

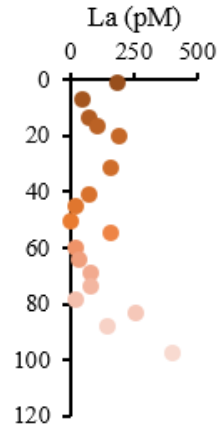
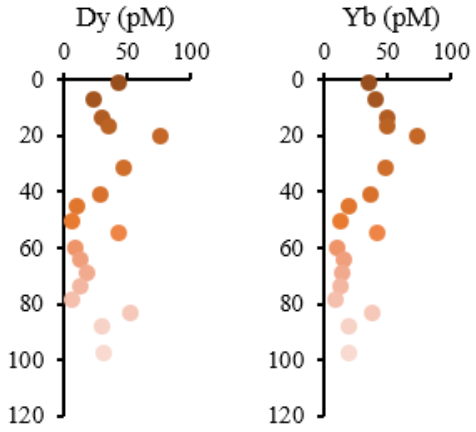

C.

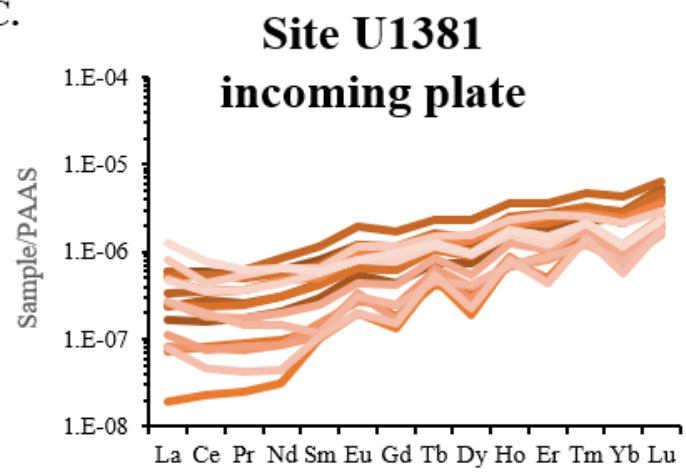

Figure F5. (A) Site U1381 and (B) U1414 PAAS-normalized REE patterns for samples from the framework wedges underlying the sediments. Data from Yan and Shi, 2016.

A. Site U1381 Framework Wedge

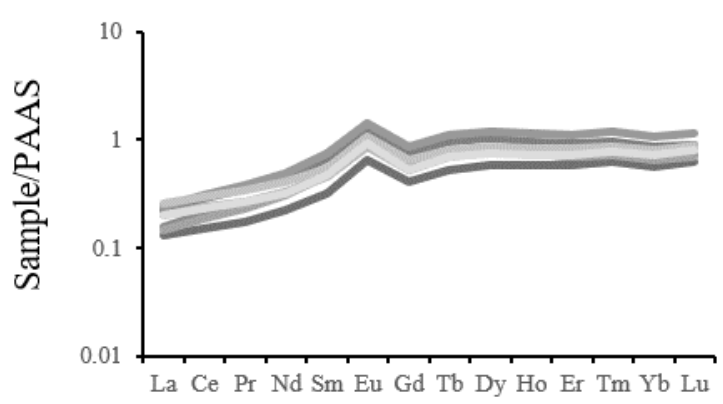

B. Site U1414 Framework Wedge

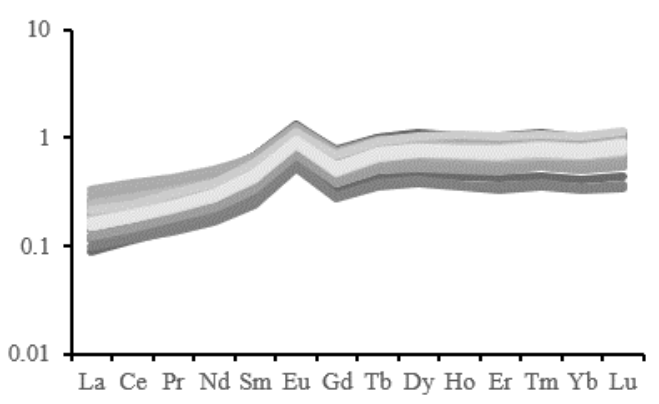


Figure F6. Pore fluid REE concentrations, Site U1414. Darker to lighter colored symbols represent samples from close to the surface of the sediment to increasing depth. A. Alkalinity, $\mathrm{NH}_{4}{ }^{+}$, and $\mathrm{Ba}^{2+}$ (from Harris et al., 2013d) and $\mathrm{La}$, Dy, and $\mathrm{Yb}$ concentrations representing the light, middle, and heavy REEs, respectively. B. PAAS-normalized $(\mathrm{Tb} / \mathrm{La})_{\mathrm{N}},(\mathrm{Yb} / \mathrm{La})_{\mathrm{N}}$, and $(\mathrm{Yb} / \mathrm{Tb})_{\mathrm{N}}$ ratios showing relative abundances of the light, middle, and heavy REEs to each other. C. PAAS-normalized REE patterns.

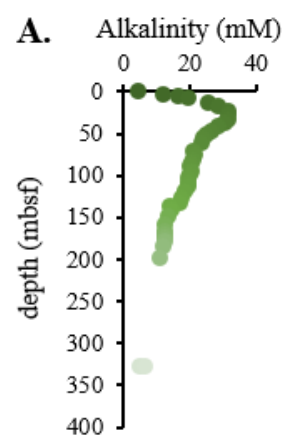

B.

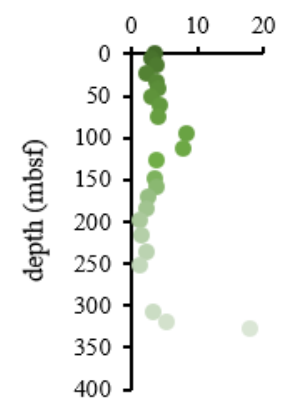

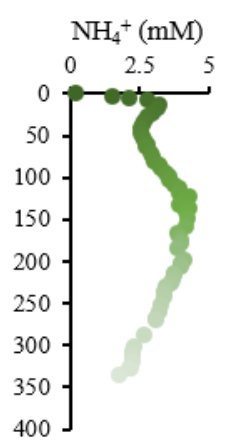

$(\mathrm{Yb} / \mathrm{La})_{\mathrm{N}}$

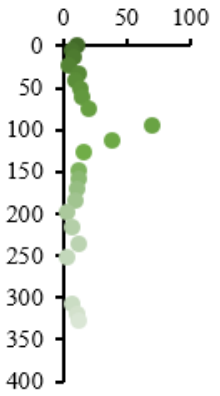

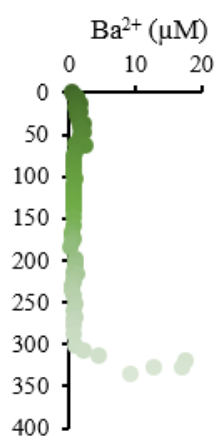

$(\mathrm{Yb} / \mathrm{Dy})_{\mathrm{N}}$

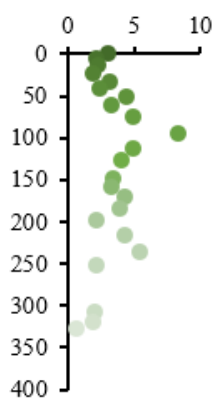

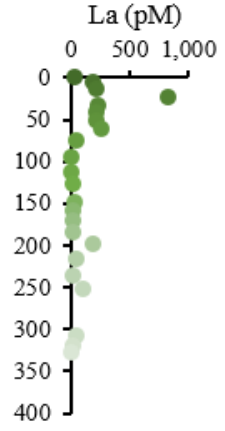
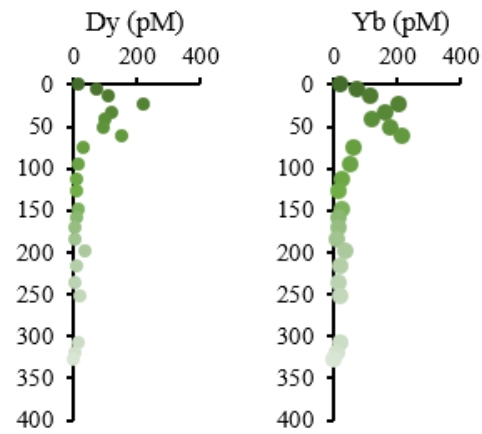

C.

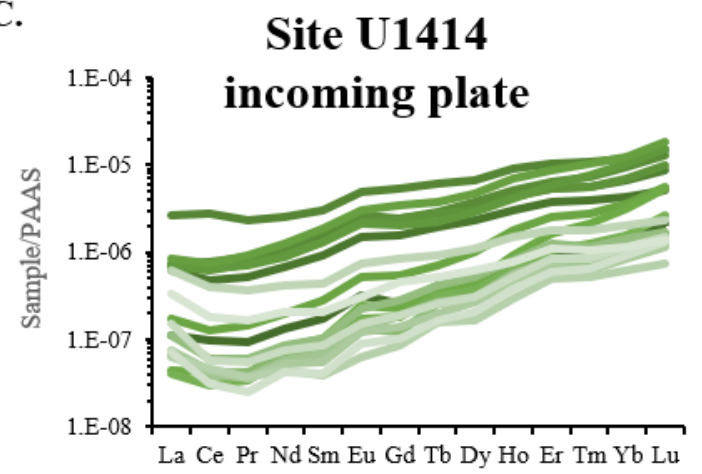

Figure F7. Correlations between pore fluid REE concentrations and alkalinity, Site U1414. Color and shading patterns correlate with depth profile shown in Figure F6. Dotted line = linear regression of all data points.
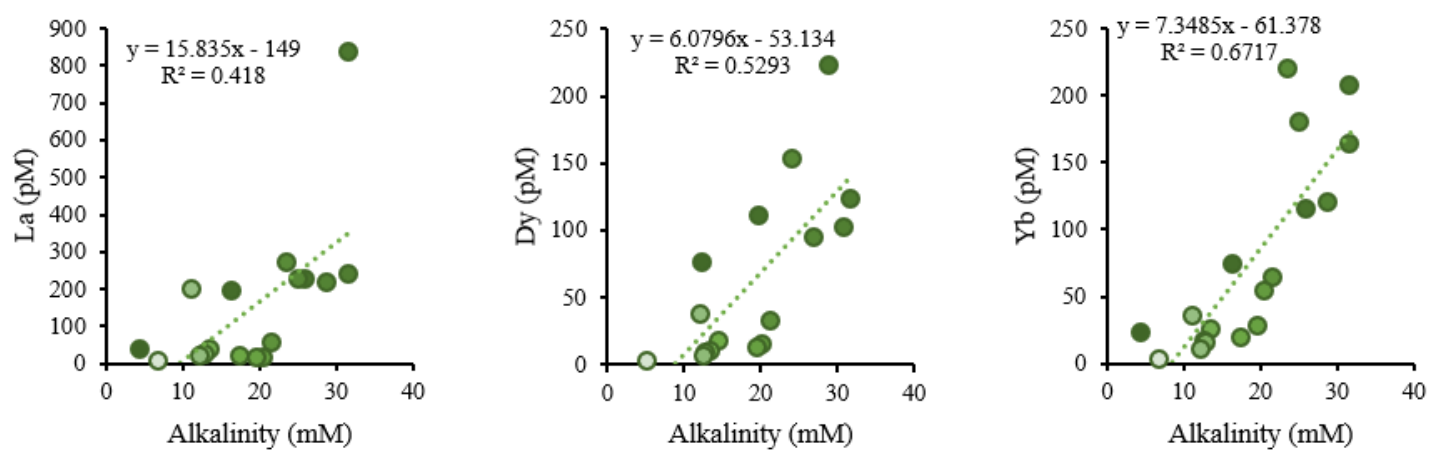
Figure F8. Correlations between pore fluid REE concentrations and dissolved $\mathrm{Ba}^{2+}$, Site U1414. Dotted green lines $=$ linear regressions for this interval.
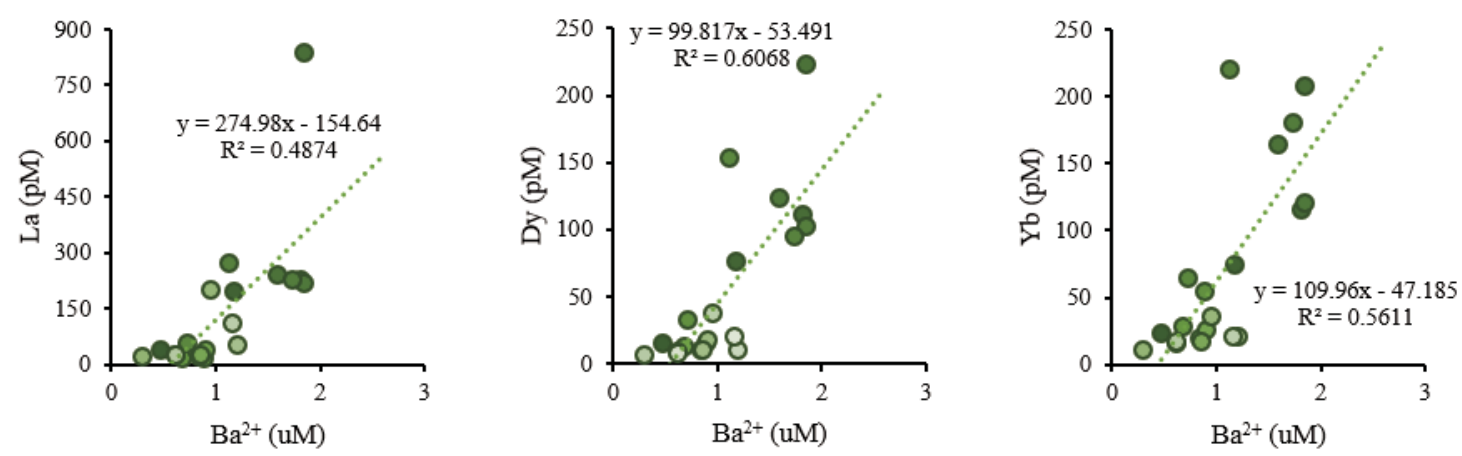
Table T1. Reproducibility and external reproducibility of the seaFAST2 method.

\begin{tabular}{|c|c|c|c|c|c|c|c|c|c|c|c|c|c|c|c|}
\hline $\begin{array}{c}\text { Standard/Reference } \\
\text { material }\end{array}$ & Rare earth element: & La & $\mathrm{Ce}$ & $\operatorname{Pr}$ & $\mathrm{Nd}$ & Sm & $\mathrm{Eu}$ & Gd & $\mathrm{Tb}$ & Dy & Ho & $\mathrm{Er}$ & $\mathrm{Tm}$ & $\mathrm{Yb}$ & Lu \\
\hline \multirow[t]{2}{*}{ NBP1097 $(N=18)$} & Average (pM): & 39.8 & 19.8 & 7.1 & 27.3 & 6.2 & 2.2 & 7.5 & 2.6 & 9.3 & 3.5 & 8.3 & 2.4 & 9.3 & 2.4 \\
\hline & $1 \sigma(\mathrm{pM})$ & 3.2 & 4.0 & 0.4 & 2.1 & 0.7 & 0.2 & 1.7 & 0.1 & 0.4 & 0.1 & 0.4 & 0.05 & 0.5 & 0.1 \\
\hline \multirow[t]{3}{*}{ PPREE1 $(N=10)$} & Average (ppm): & 85.9 & 171.5 & 21.5 & 95.1 & 21.9 & 6.5 & 26.2 & 4.4 & 23.8 & 4.9 & 12.7 & 1.9 & 8.9 & 1.3 \\
\hline & $1 \sigma(p p m):$ & 6.4 & 10.7 & 1.2 & 4.7 & 1.4 & 0.3 & 1.9 & 0.6 & 1.8 & 0.7 & 0.4 & 0.7 & 0.6 & 0.1 \\
\hline & Most probable value $(\mathrm{ppm})^{*}$ : & 80.4 & 161.2 & 21.2 & 92.3 & 20.3 & 5.95 & 23.8 & 3.65 & 22.0 & 4.43 & 11.9 & 1.48 & 8.2 & 1.12 \\
\hline
\end{tabular}

* = from Verplanck et al., 2001. RSD = relative standard deviation.

Table T2. Pore fluid REE concentrations, Sites U1378 and U1380.

\begin{tabular}{|c|c|c|c|c|c|c|c|c|c|c|c|c|c|c|c|}
\hline Core, section & $\begin{array}{l}\text { Depth } \\
\text { (mbsf) }\end{array}$ & $\begin{array}{c}\mathrm{La} \\
(\mathrm{pM})\end{array}$ & $\begin{array}{c}\mathrm{Ce} \\
(\mathrm{pM})\end{array}$ & $\begin{array}{c}\mathrm{Pr} \\
(\mathrm{pM})\end{array}$ & $\begin{array}{c}\mathrm{Nd} \\
(\mathrm{pM})\end{array}$ & $\begin{array}{l}\mathrm{Sm} \\
(\mathrm{pM})\end{array}$ & $\begin{array}{c}\mathrm{Eu} \\
(\mathrm{pM})\end{array}$ & $\begin{array}{c}\mathrm{Gd} \\
(\mathrm{pM})\end{array}$ & $\begin{array}{c}\mathrm{Tb} \\
(\mathrm{pM})\end{array}$ & $\begin{array}{c}\text { Dy } \\
\text { (pM) }\end{array}$ & $\begin{array}{l}\mathrm{Ho} \\
(\mathrm{pM})\end{array}$ & $\begin{array}{c}\mathrm{Er} \\
(\mathrm{pM})\end{array}$ & $\begin{array}{c}\operatorname{Tm} \\
(\mathrm{pM})\end{array}$ & $\begin{array}{c}\mathrm{Yb} \\
(\mathrm{pM})\end{array}$ & $\begin{array}{c}\mathrm{Lu} \\
(\mathrm{pM})\end{array}$ \\
\hline \multicolumn{16}{|l|}{ 334-U1378B- } \\
\hline $1 \mathrm{H}-1$ & 1.38 & 47 & 94 & 11 & 52 & 16 & 5 & 20 & 6 & 27 & 13 & 42 & 6 & 29 & 7 \\
\hline $1 \mathrm{H}-4$ & 4.96 & 57 & 145 & 15 & 79 & 24 & 7 & 34 & 8 & 48 & 16 & 49 & 10 & 52 & 11 \\
\hline $2 \mathrm{H}-3$ & 9.68 & 122 & 370 & 35 & 177 & 48 & 14 & 65 & 13 & 80 & 24 & 80 & 12 & 71 & 14 \\
\hline $2 \mathrm{H}-4$ & 11.18 & 133 & 338 & 39 & 204 & 54 & 16 & 79 & 16 & 102 & 31 & 109 & 15 & 88 & 17 \\
\hline $3 \mathrm{H}-1$ & 16.18 & 162 & 449 & 43 & 223 & 59 & 17 & 82 & 17 & 120 & 38 & 132 & 22 & 145 & 29 \\
\hline $3 \mathrm{H}-6$ & 23.63 & 9 & 18 & 3 & 16 & 7 & 3 & 12 & 5 & 40 & 18 & 69 & 14 & 97 & 22 \\
\hline $5 \mathrm{H}-6$ & 42.68 & 27 & 59 & 8 & 37 & 12 & 4 & 16 & 5 & 26 & 11 & 33 & 8 & 43 & 11 \\
\hline $8 \mathrm{H}-2$ & 63.82 & 17 & 38 & 6 & 29 & 10 & 4 & 15 & 5 & 24 & 15 & 51 & 7 & 37 & 9 \\
\hline $9 \mathrm{H}-5$ & 79.10 & 81 & 197 & 26 & 132 & 33 & 11 & 44 & 9 & 60 & 26 & 91 & 8 & 65 & 12 \\
\hline $10 \mathrm{H}-4$ & 87.10 & 95 & 201 & 29 & 157 & 45 & 14 & 67 & 13 & 81 & 24 & 74 & 13 & 81 & 17 \\
\hline $13 \mathrm{H}-4$ & 107.88 & 99 & 262 & 34 & 170 & 48 & 15 & 65 & 14 & 90 & 26 & 81 & 11 & 84 & 14 \\
\hline $15 \mathrm{H}-2$ & 118.48 & 50 & 103 & 15 & 75 & 22 & 7 & 30 & 7 & 36 & 18 & 55 & 7 & 40 & 9 \\
\hline $17 X-3$ & 132.13 & 50 & 113 & 17 & 91 & 24 & 8 & 36 & 8 & 48 & 13 & 45 & 6 & 45 & 8 \\
\hline $19 X-5$ & 148.55 & 65 & 137 & 20 & 101 & 29 & 10 & 40 & 9 & 54 & 20 & 62 & 10 & 63 & 13 \\
\hline $34 X-2$ & 277.96 & 87 & 192 & 25 & 128 & 36 & 14 & 44 & 10 & 62 & 16 & 56 & 7 & 53 & 8 \\
\hline $35 X-5$ & 292.08 & 108 & 220 & 30 & 142 & 35 & 14 & 45 & 10 & 53 & 13 & 38 & 5 & 39 & 6 \\
\hline $37 X-2$ & 307.21 & 97 & 226 & 29 & 135 & 35 & 12 & 44 & 9 & 51 & 14 & 40 & 7 & 38 & 8 \\
\hline $41 X-5$ & 340.74 & 57 & 107 & 16 & 75 & 21 & 8 & 28 & 7 & 35 & 11 & 30 & 6 & 30 & 7 \\
\hline $47 X-2$ & 379.35 & 30 & 50 & 7 & 32 & 10 & 4 & 14 & 4 & 15 & 6 & 13 & 4 & 13 & 5 \\
\hline $50 X-2$ & 402.27 & 46 & 68 & 10 & 44 & 12 & 5 & 17 & 5 & 21 & 8 & 18 & 5 & 18 & 6 \\
\hline $56 X-2$ & 458.24 & 22 & 42 & 6 & 27 & 9 & 3 & 11 & 4 & 14 & 7 & 16 & 4 & 14 & 5 \\
\hline \multicolumn{16}{|l|}{ 334-U1380A- } \\
\hline 10R-3 & 475.15 & 94 & 191 & 27 & 124 & 34 & 21 & 39 & 9 & 45 & 14 & 42 & 7 & 33 & 8 \\
\hline \multicolumn{16}{|l|}{ 344-U1380C- } \\
\hline $3 R-3$ & 451.94 & 161 & 328 & 42 & 174 & 39 & 12 & 45 & 9 & 46 & 13 & 38 & 7 & 35 & 8 \\
\hline
\end{tabular}


Table T3. Pore fluid REE concentrations, Site U1381.

\begin{tabular}{|c|c|c|c|c|c|c|c|c|c|c|c|c|c|c|c|}
\hline Core, section & $\begin{array}{l}\text { Depth } \\
\text { (mbsf) }\end{array}$ & $\begin{array}{c}\mathrm{La} \\
(\mathrm{pM})\end{array}$ & $\begin{array}{c}\mathrm{Ce} \\
(\mathrm{pM})\end{array}$ & $\begin{array}{c}\mathrm{Pr} \\
(\mathrm{pM})\end{array}$ & $\begin{array}{c}\mathrm{Nd} \\
(\mathrm{pM})\end{array}$ & $\begin{array}{l}\mathrm{Sm} \\
(\mathrm{pM})\end{array}$ & $\begin{array}{c}\mathrm{Eu} \\
(\mathrm{pM})\end{array}$ & $\begin{array}{c}\mathrm{Gd} \\
(\mathrm{pM})\end{array}$ & $\begin{array}{c}\mathrm{Tb} \\
(\mathrm{pM})\end{array}$ & $\begin{array}{c}\text { Dy } \\
\text { (pM) }\end{array}$ & $\begin{array}{c}\mathrm{Ho} \\
(\mathrm{pM})\end{array}$ & $\begin{array}{c}\mathrm{Er} \\
(\mathrm{pM})\end{array}$ & $\begin{array}{c}\mathrm{Tm} \\
(\mathrm{pM})\end{array}$ & $\begin{array}{c}\mathrm{Yb} \\
(\mathrm{pM})\end{array}$ & $\begin{array}{c}\mathrm{Lu} \\
(\mathrm{pM})\end{array}$ \\
\hline \multicolumn{16}{|l|}{ 344-U1381C- } \\
\hline $1 \mathrm{H}-1$ & 1.45 & 192 & 374 & 38 & 161 & 37 & 10 & 41 & 9 & 43 & 15 & 46 & 8 & 36 & 10 \\
\hline $1 \mathrm{H}-5$ & 7.45 & 52 & 102 & 13 & 54 & 13 & 4 & 17 & 4 & 24 & 8 & 32 & 6 & 42 & 11 \\
\hline $2 \mathrm{H}-4$ & 14.05 & 75 & 181 & 19 & 79 & 20 & 5 & 24 & 6 & 31 & 13 & 38 & 9 & 50 & 14 \\
\hline $2 \mathrm{H}-6$ & 17.05 & 108 & 218 & 27 & 116 & 26 & 8 & 31 & 6 & 36 & 12 & 46 & 7 & 50 & 12 \\
\hline $3 \mathrm{H}-2$ & 20.55 & 193 & 323 & 45 & 220 & 52 & 15 & 67 & 13 & 76 & 23 & 67 & 13 & 74 & 16 \\
\hline $4 \mathrm{H}-3$ & 31.55 & 166 & 342 & 36 & 149 & 33 & 9 & 43 & 9 & 48 & 16 & 51 & 9 & 49 & 12 \\
\hline $5 \mathrm{H}-3$ & 41.07 & 78 & 151 & 18 & 80 & 19 & 5 & 24 & 6 & 29 & 14 & 38 & 7 & 37 & 10 \\
\hline $5 \mathrm{H}-6$ & 45.57 & 24 & 53 & 6 & 26 & 6 & 3 & 7 & 2 & 11 & 4 & 17 & 4 & 21 & 6 \\
\hline $6 \mathrm{H}-3$ & 50.585 & 6 & 14 & 2 & 8 & 5 & 2 & 5 & 3 & 6 & 5 & 9 & 4 & 14 & 6 \\
\hline $6 \mathrm{H}-6$ & 55.085 & 160 & 219 & 27 & 121 & 23 & 8 & 36 & 6 & 44 & 13 & 47 & 7 & 43 & 9 \\
\hline $7 \mathrm{H}-3$ & 60.025 & 27 & 49 & 5 & 22 & 7 & 2 & 9 & 3 & 9 & 6 & 8 & 4 & 10 & 5 \\
\hline $7 \mathrm{H}-6$ & 64.525 & 36 & 47 & 6 & 23 & 5 & 3 & 7 & 4 & 13 & 4 & 15 & 3 & 16 & 5 \\
\hline $8 \mathrm{H}-3$ & 69.545 & 85 & 115 & 12 & 51 & 12 & 3 & 16 & 5 & 18 & 8 & 19 & 5 & 15 & 5 \\
\hline $8 \mathrm{H}-6$ & 74.065 & 85 & 126 & 10 & 38 & 5 & 2 & 10 & 3 & 14 & 5 & 16 & 3 & 13 & 4 \\
\hline $9 \mathrm{H}-3$ & 79.025 & 25 & 29 & 3 & 11 & 5 & 2 & 6 & 3 & 7 & 5 & 8 & 4 & 10 & 5 \\
\hline $9 \mathrm{H}-6$ & 83.525 & 260 & 276 & 39 & 166 & 30 & 9 & 45 & 9 & 52 & 15 & 50 & 7 & 38 & 7 \\
\hline $10 \mathrm{H}-3$ & 88.55 & 151 & 223 & 27 & 113 & 26 & 7 & 30 & 7 & 31 & 10 & 22 & 6 & 21 & 6 \\
\hline $11 \mathrm{H}-3$ & 98.05 & 409 & 484 & 46 & 171 & 27 & 7 & 36 & 7 & 31 & 11 & 28 & 6 & 20 & 6 \\
\hline
\end{tabular}

Table T4. Pore fluid REE concentrations, Site U1414.

\begin{tabular}{|c|c|c|c|c|c|c|c|c|c|c|c|c|c|c|c|}
\hline Core, section & $\begin{array}{l}\text { Depth } \\
\text { (mbsf) }\end{array}$ & $\begin{array}{c}\mathrm{La} \\
(\mathrm{pM})\end{array}$ & $\begin{array}{c}\mathrm{Ce} \\
(\mathrm{pM})\end{array}$ & $\begin{array}{c}\mathrm{Pr} \\
(\mathrm{pM})\end{array}$ & $\begin{array}{c}\mathrm{Nd} \\
(\mathrm{pM})\end{array}$ & $\begin{array}{c}\mathrm{Sm} \\
(\mathrm{pM})\end{array}$ & $\begin{array}{c}\mathrm{Eu} \\
(\mathrm{pM})\end{array}$ & $\begin{array}{c}\mathrm{Gd} \\
(\mathrm{pM})\end{array}$ & $\begin{array}{c}\mathrm{Tb} \\
(\mathrm{pM})\end{array}$ & $\begin{array}{c}\text { Dy } \\
(\mathrm{pM})\end{array}$ & $\begin{array}{c}\text { Ho } \\
(\mathrm{pM})\end{array}$ & $\begin{array}{c}\mathrm{Er} \\
(\mathrm{pM})\end{array}$ & $\begin{array}{c}\operatorname{Tm} \\
(\mathrm{pM})\end{array}$ & $\begin{array}{c}\mathrm{Yb} \\
(\mathrm{pM})\end{array}$ & $\begin{array}{c}\mathrm{Lu} \\
(\mathrm{pM})\end{array}$ \\
\hline \multicolumn{16}{|l|}{ 344-U1414A- } \\
\hline $1 \mathrm{H}-1$ & 0.56 & 37 & 63 & 7 & 34 & 8 & 3 & 10 & 2 & 15 & 5 & 17 & 3 & 23 & 5 \\
\hline $2 \mathrm{H}-3$ & 6.08 & 196 & 301 & 38 & 176 & 43 & 12 & 60 & 11 & 75 & 19 & 69 & 11 & 74 & 13 \\
\hline $3 \mathrm{H}-2$ & 14.17 & 224 & 458 & 55 & 253 & 67 & 19 & 93 & 16 & 111 & 28 & 97 & 15 & 115 & 22 \\
\hline $4 \mathrm{H}-2$ & 23.67 & 834 & 1764 & 169 & 652 & 137 & 39 & 206 & 34 & 223 & 58 & 191 & 29 & 207 & 37 \\
\hline $5 \mathrm{H}-2$ & 33.17 & 239 & 486 & 64 & 290 & 77 & 21 & 95 & 16 & 123 & 33 & 119 & 20 & 164 & 33 \\
\hline $6 \mathrm{H}-2$ & 42.75 & 217 & 398 & 53 & 236 & 60 & 18 & 88 & 16 & 101 & 27 & 97 & 15 & 120 & 25 \\
\hline $7 \mathrm{H}-2$ & 52.35 & 227 & 402 & 52 & 227 & 59 & 17 & 77 & 13 & 94 & 27 & 106 & 20 & 179 & 38 \\
\hline $8 \mathrm{H}-2$ & 61.85 & 269 & 468 & 66 & 323 & 84 & 24 & 131 & 21 & 153 & 45 & 163 & 27 & 219 & 45 \\
\hline $9 \mathrm{H}-5$ & 75.85 & 57 & 81 & 10 & 52 & 13 & 4 & 21 & 4 & 33 & 11 & 46 & 7 & 64 & 14 \\
\hline $11 \mathrm{H}-5$ & 94.85 & 14 & 27 & 3 & 21 & 5 & 2 & 9 & 2 & 15 & 6 & 30 & 6 & 54 & 13 \\
\hline $13 \mathrm{H}-5$ & 113.85 & 13 & 19 & 2 & 16 & 4 & 1 & 7 & 2 & 12 & 4 & 19 & 3 & 28 & 7 \\
\hline $15 \mathrm{H}-2$ & 128.35 & 21 & 26 & 3 & 16 & 3 & 1 & 5 & 1 & 9 & 3 & 16 & 2 & 19 & 4 \\
\hline $17 \mathrm{H}-4$ & 150.325 & 35 & 38 & 4 & 22 & 5 & 2 & 11 & 2 & 17 & 5 & 23 & 3 & 25 & 4 \\
\hline $18 \mathrm{H}-5$ & 159.43 & 23 & 24 & 3 & 15 & 3 & 1 & 7 & 2 & 10 & 4 & 15 & 2 & 16 & 3 \\
\hline $19 \mathrm{H}-6$ & 170.655 & 24 & 28 & 3 & 14 & 3 & 1 & 5 & 1 & 9 & 3 & 13 & 2 & 15 & 3 \\
\hline $21 \mathrm{H}-3$ & 185.525 & 20 & 30 & 3 & 11 & 2 & 0 & 3 & 1 & 5 & 2 & 9 & 1 & 11 & 2 \\
\hline $22 \mathrm{H}-6$ & 198.875 & 197 & 252 & 26 & 109 & 20 & 6 & 33 & 5 & 37 & 10 & 33 & 5 & 36 & 6 \\
\hline $24 X-6$ & 217.85 & 49 & 36 & 4 & 19 & 4 & 1 & 7 & 1 & 10 & 3 & 15 & 2 & 20 & 4 \\
\hline $26 X-5$ & 236.30 & 23 & 19 & 2 & 11 & 2 & 1 & 4 & 1 & 7 & 2 & 11 & 2 & 16 & 3 \\
\hline $28 X-4$ & 252.93 & 108 & 113 & 12 & 54 & 10 & 3 & 17 & 3 & 20 & 5 & 20 & 3 & 20 & 3 \\
\hline
\end{tabular}




\section{Appendix}

Tables AT1, AT2, and AT3 contain sample aliquot information and instrument operating conditions for each pore fluid analytical run. 
Table AT1. Sample aliquot volumes used during pore fluid analyses.

\begin{tabular}{lc}
\hline Core, section & $\begin{array}{c}\text { Sample aliquot } \\
\text { measured } \\
(\mathrm{mL})\end{array}$ \\
\hline $334-\mathrm{U} 1378 \mathrm{~B}-$ & \\
$1 \mathrm{H}-1$ & 2 \\
$1 \mathrm{H}-4$ & 2 \\
$2 \mathrm{H}-3$ & 2 \\
$2 \mathrm{H}-4$ & 2 \\
$3 \mathrm{H}-1$ & 2 \\
$3 \mathrm{H}-6$ & 2 \\
$5 \mathrm{H}-6$ & 2 \\
$8 \mathrm{H}-2$ & 2 \\
$9 \mathrm{H}-5$ & 2 \\
$10 \mathrm{H}-4$ & 2 \\
$13 \mathrm{H}-4$ & 2 \\
$15 \mathrm{H}-2$ & 2 \\
$17 \mathrm{X}-3$ & 2 \\
$19 \mathrm{X}-5$ & 2 \\
$34 \mathrm{X}-2$ & 2 \\
$35 \mathrm{X}-5$ & 2 \\
$37 \mathrm{X}-2$ & 2 \\
$41 \mathrm{X}-5$ & 2 \\
$47 \mathrm{X}-2$ & 2 \\
$50 \mathrm{X}-2$ & 2 \\
$56 \mathrm{X}-2$ &
\end{tabular}

\begin{tabular}{lc}
\hline Core, section & $\begin{array}{c}\text { Sample aliquot } \\
\text { measured } \\
(\mathrm{mL})\end{array}$ \\
\hline $334-\mathrm{U} 1380 \mathrm{~A}-$ & \\
10R-3 & 2 \\
$344-\mathrm{U} 1380 \mathrm{C}-$ & \\
$3 \mathrm{R}-3$ & 2 \\
$344-\mathrm{U} 1381 \mathrm{C}-$ & \\
$1 \mathrm{H}-1$ & 2.5 \\
$1 \mathrm{H}-5$ & 2.5 \\
$2 \mathrm{H}-4$ & 2.5 \\
$2 \mathrm{H}-6$ & 2.5 \\
$3 \mathrm{H}-2$ & 2.5 \\
$4 \mathrm{H}-3$ & 2.5 \\
$5 \mathrm{H}-3$ & 2.5 \\
$5 \mathrm{H}-6$ & 2.5 \\
$6 \mathrm{H}-3$ & 2.5 \\
$6 \mathrm{H}-6$ & 2.5 \\
$7 \mathrm{H}-3$ & 2.5 \\
$7 \mathrm{H}-6$ & 2.5 \\
$8 \mathrm{H}-3$ & 2.5 \\
$8 \mathrm{H}-6$ & 2.5 \\
$9 \mathrm{H}-3$ & 2.5 \\
$9 \mathrm{H}-6$ & 2.5 \\
$10 \mathrm{H}-3$ & 2.5 \\
$11 \mathrm{H}-3$ & 2.5 \\
&
\end{tabular}

\begin{tabular}{lc}
\hline Core, section & $\begin{array}{c}\text { Sample aliquot } \\
\text { measured } \\
(\mathrm{mL})\end{array}$ \\
\hline 344-U1414A- & \\
$1 \mathrm{H}-1$ & 3 \\
$2 \mathrm{H}-3$ & 3 \\
$3 \mathrm{H}-2$ & 3 \\
$4 \mathrm{H}-2$ & 3 \\
$5 \mathrm{H}-2$ & 3 \\
$6 \mathrm{H}-2$ & 3 \\
$7 \mathrm{H}-2$ & 3 \\
$8 \mathrm{H}-2$ & 3 \\
$9 \mathrm{H}-5$ & 3 \\
$11 \mathrm{H}-5$ & 3 \\
$13 \mathrm{H}-5$ & 3 \\
$15 \mathrm{H}-2$ & 3 \\
$17 \mathrm{H}-4$ & 3 \\
$18 \mathrm{H}-5$ & 3 \\
$19 \mathrm{H}-6$ & 3 \\
$21 \mathrm{H}-3$ & 3 \\
$22 \mathrm{H}-6$ & 3 \\
$24 \mathrm{X}-6$ & 3 \\
$26 \mathrm{X}-5$ & 3 \\
$28 \mathrm{X}-4$ & 3 \\
\hline
\end{tabular}

Table AT2. Thermo X-SeriesII inductively coupled plasma-mass spectrometer operating conditions.

\begin{tabular}{rc}
\hline RF power $(\mathrm{W}):$ & 1400 \\
Cool gas flow $(\mathrm{L} / \mathrm{min}):$ & 13 \\
Auxiliary gas flow $(\mathrm{L} / \mathrm{min}):$ & 0.8 \\
Nebulizer gas flow $(\mathrm{L} / \mathrm{min}):$ & 0.8 \\
Data acquisition: & Time-resolved analysis \\
Dwell time (ms): & 10 \\
Cones: & Nickel \\
Isotopes monitored: & ${ }^{137} \mathrm{Ba},{ }^{139} \mathrm{La},{ }^{140} \mathrm{Ce},{ }^{141} \mathrm{Pr},{ }^{146} \mathrm{Nd},{ }^{147} \mathrm{Sm},{ }^{153} \mathrm{Eu}$, \\
& ${ }^{157} \mathrm{Gd},{ }^{159} \mathrm{~Tb},{ }^{163} \mathrm{Dy},{ }^{165} \mathrm{Ho},{ }^{166} \mathrm{Er},{ }^{169} \mathrm{Tm},{ }^{172} \mathrm{Yb},{ }^{175} \mathrm{Lu}$ \\
Oxide formation $(\mathrm{CeO} / \mathrm{Ce})(\%):$ & $<3$ \\
\hline
\end{tabular}

Table AT3. Instrument sensitivity per run as indicated by the signal of an internal standard $\left({ }^{115} \operatorname{In}\right)$.

\begin{tabular}{clll}
\hline $\begin{array}{c}\text { Run date } \\
\text { (2013) }\end{array}$ & Expedition & \multicolumn{1}{c}{ Site } & $\begin{array}{l}\text { Sensitivity } \\
\text { (counts/s) }\end{array}$ \\
\hline 6 Aug & $334 / 344$ & U1378/U1380 & $6,654,155$ \\
& 344 & $\begin{array}{l}\text { U1381 } \\
\text { U1381 }\end{array}$ & $7,840,588$ \\
\hline
\end{tabular}

